\title{
Should percutaneous cholecystostomy be used in all cases difficult to manage?
}

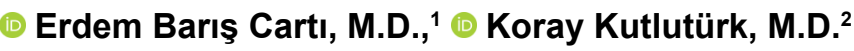

${ }^{1}$ Department of General Surgery, Adnan Menderes University Faculty of Medicine, Aydın-Turkey

${ }^{2}$ Department of General Surgery, İönü University Faculty of Medicine, Malatya-Turkey

\begin{abstract}
BACKGROUND: Cholecystectomy is the well-accepted management method for acute cholecystitis in patients suitable for surgery. Percutaneous cholecystostomy is planned and used in patients at high surgical risk due to acute symptomatic cholecystitis and/or acute or chronic comorbidity. Percutaneous cholecystostomy can provide permanent treatment, or it may act as a bridge for elective cholecystectomy.
\end{abstract}

METHODS: We presented the outcomes of 50 patients who initially underwent ultrasound-guided transhepatic percutaneous cholecystostomy and 4-6 weeks later, an interval cholecystectomy. All patients had either impaired gallbladder wall integrity on contrastenhanced abdominal computed tomography performed during admission or had grade II acute cholecystitis according to the Tokyo Guidelines 13 diagnostic criteria and severity grading of acute cholecystitis or exhibited clinical signs of acute cholecystitis on the fifth day of non-operative treatment.

RESULTS: Our results suggest that although percutaneous cholecystostomy is a useful method for alleviation of the emergency clinical condition in acute cholecystitis, it makes the interval cholecystectomy more difficult to perform due to the dense fibrosis developing during the healing process, eventually complicating laparoscopic cholecystectomy.

CONCLUSION: Cholecystostomy may cause fibrosis during the healing process, eventually complicating laparoscopic cholecystectomy. Thus, there is a need for better evaluation during the identification of indications for cholecystostomy.

Keywords: Acute cholecystitis; laparoscopic cholecystectomy; open cholecystectomy; percutaneous cholecystostomy.

\section{INTRODUCTION}

Acute cholecystitis is one of the common causes of acute abdominal pain. Acute calculous cholecystitis that occurs due to obstruction of the gallbladder neck or the cystic duct with gallstones is responsible for the pathophysiology of up to $90 \%$ of these cases. ${ }^{[1]}$ Cholecystectomy is the well-accepted management method for acute cholecystitis in patients suitable for surgery. Laparoscopic cholecystectomy, a minimally invasive technique, is now the standard treatment option in the management of benign biliary disorders, including acute cholecystitis. ${ }^{[2]}$

According to the Tokyo guidelines, which was first published in 2007 concerning the diagnostic criteria and severity grading of acute cholecystitis and was updated in 2013, the acute cholecystitis is classified into three grades, mild (grade I), moderate (grade II), and severe (grade III). Grade I (mild acute cholecystitis) is defined as acute cholecystitis in a patient with no organ dysfunction and limited disease in the gallbladder, making cholecystectomy a low-risk procedure. Grade II (moderate acute cholecystitis) is associated with no organ dysfunction; however, there is an extensive disease in the gallbladder, resulting in increased difficulty in safely performing a cholecystectomy and an increased risk of biliary tract injury during the inflammation-related cholecystectomy surgery. Grade III (severe acute cholecystitis) is defined as acute cholecystitis with organ dysfunction. ${ }^{[3]}$

Cite this article as: Cartı EB, Kutlutürk K. Should percutaneous cholecystostomy be used in all cases difficult to manage?. Ulus Travma Acil Cerrahi Derg 2020;26:186-190.

Address for correspondence: Erdem Barış Cartı, M.D.

Adnan Menderes Üniversitesi Tıp Fakültesi, Genel Cerrahi Kliniği, Aydın, Turkey

Tel: +90 850 - 3401256 E-mail: erdemcarti@yahoo.com

Ulus Travma Acil Cerrahi Derg 2020;26(2):186-190 DOI: 10.14744/tjtes.2020.73557 Submitted: 0I.10.2019 Accepted: II.02.2020 Online: 21.02.2020

Copyright 2020 Turkish Association of Trauma and Emergency Surgery 
Computed tomography is useful in diagnosing complicated acute cholecystitis (emphysematous, gangrenous, and perforated). In addition, it is particularly useful in the differential diagnosis of other intraabdominal disorders in patients in whom the use of abdominal ultrasound (US) is limited, such as the obese patients or patients with abdominal gaseous distension. ${ }^{[4]}$

Percutaneous cholecystostomy (PC) is planned and used in patients at high surgical risk due to acute symptomatic cholecystitis and/or acute or chronic comorbidity. Draining the infected bile via a percutaneous cholecystostomy contributes to the resolution of inflammation, leading to an improvement in clinical status. ${ }^{[5]}$

Our aim in this study was to present and compare with the literature the outcomes of ultrasound-guided transhepatic percutaneous cholecystostomy performed patients in our clinic.

\section{MATERIALS AND METHODS}

A total of 512 patients with acute calculous cholecystitis were admitted to the General Surgery Clinic of Adnan Memderes University Training and Research Hospital between March 2016 and March 2018. Among these, 66 patients who were at high surgical risk due to acute symptomatic cholecystitis and/or acute or chronic comorbidity underwent ultrasoundguided transhepatic percutaneous cholecystostomy under local anesthesia with a pigtail catheter by an interventional radiologist. Fifteen patients underwent percutaneous cholecystostomy due to acute or chronic comorbidities and the presence of high postoperative mortality risk (Tokyo grade III) and were excluded from this study. One patient developed free perforation of the gallbladder during the procedure and was excluded from this study due to the need for an emergency operation after the procedure.

All of the 50 patients included in this study had impaired gallbladder wall integrity (intraparenchymal fluid in the gallbladder bed or excess fluid around the gallbladder, together with ongoing gallbladder distension) on contrast-enhanced abdominal CT performed during admission or had grade II acute cholecystitis according to the TGI 3 diagnostic criteria and severity grading of acute cholecystitis exhibited clinical signs of acute cholecystitis on day five despite non-operative treatment (discontinuation of oral intake, intravenous hydration, and intravenous ceftriaxone treatment), and underwent ultrasound-guided transhepatic percutaneous cholecystostomy initially and 4-6 weeks later, an interval cholecystectomy in our clinic. We retrospectively investigated the outcomes of these patients.

\section{Statistical Analysis}

The Statistical Package for the Social Sciences (SPSS 21.0 software, IL-Chicago- USA) was used for data analyses. De- scriptive analysis was carried out for demographic and clinical features. The results were presented as percentages for continuous variables, and the number/percentage for categorical variables.

\section{RESULTS}

The mean age of 50 patients included in this study was $\mathbf{5 2 . 5}$ years. The male/female ratio was I.6. In all patients, the symptoms (right upper quadrant pain, fever, and fatigue) improved after percutaneous cholecystostomy. On the first few days after percutaneous cholecystostomy, some patients required daily recurrent saline irrigations through the cholecystostomy drainage catheter for removing the dense contents of the gallbladder. Oral food intake was started when post-procedural relief was observed, and solid foods were gradually administered. The mean hospital stay after percutaneous cholecystostomy was 1.8 days. Our patients were discharged following training for changing the dressing around the entry hole for cholecystostomy, the evacuation of the cholecystostomy tube, and with an oral antibiotic prescription, diet recommendation, together with an outpatient appointment.

In the General Surgery Outpatient Clinic, all patients were examined by the surgeon who followed them during their hospitalizations, and they underwent cholecystectomy performed by the same surgeon 4-6 weeks later. The cholecystostomy catheters of the patients were withdrawn on the operating table just before the cholecystectomy operation. The operation was started with the laparoscopic approach in the first ten consecutive patients. However, the operation was converted to an open cholecystectomy procedure (anterograde or fundus-down approach) through a right subcostal incision in eight patients due to the encountered difficulties in dissection and the inability to clearly identify the anatomy. The rate of conversion from laparoscopic cholecystectomy to open cholecystectomy was calculated as $80 \%$. Since the conversion rate was high in the first 10 patients, the interval cholecystectomy following percutaneous cholecystostomy was performed as a conventional open cholecystectomy through a right subcostal incision in the remaining 40 patients. The mean postoperative hospital stay was 2.8 days with null mortality. One patient encountered a bile duct injury of Strasberg A (cystic duct stump leak) type and was discharged from hospital after a coated stent was introduced by endoscopic retrograde cholangiopancreatography (ERCP). Wound infection was detected in four patients. None of our patients developed additional morbidity.

\section{DISCUSSION}

The management of patients with acute cholecystitis in our clinic can be summarized as follows: Patients with acute cholecystitis whose present complaints during admission have not exceeded 24-48 hours undergo emergency laparoscopic cholecystectomy; patients with acute cholecystitis 
whose complaints present during admission have exceeded 24-48 hours are discharged after non-operative treatment (discontinuation of oral intake, intravenous hydration, and intravenous ceftriaxone treatment) and undergo elective laparoscopic cholecystectomy 4-6 weeks later. Patients with impaired gallbladder wall integrity (intraparenchymal fluid in the gallbladder bed or excess fluid around the gallbladder, together with ongoing gallbladder distension) on contrast-enhanced abdominal CT performed at the time of admission or who have a grade II acute cholecystitis according to the Tokyo 2013 diagnostic criteria and severity grading guidelines of acute cholecystitis who exhibit clinical signs of acute cholecystitis on day five despite non-operative treatment (discontinuation of oral intake, intravenous hydration, and intravenous ceftriaxone treatment), undergo ultrasound-guided transhepatic percutaneous cholecystostomy procedure initially and 4-6 weeks later, an interval cholecystectomy in our clinic. Our treatment protocol was shown in Figure I.

Cholecystectomy, when used as the first treatment approach for cholecystitis in high-risk patients, has been reported to have a morbidity rate of $62 \%$ and a mortality rate of $50 \%{ }^{[6-9]}$ Even though our patients were classified as grade II according to the TGI 3 diagnostic criteria and severity grading of acute cholecystitis, all patients were either not able to respond to administered intravenous antibiotics or had impaired gallbladder wall integrity (Fig. I) (intraparenchymal fluid in the gallbladder bed or excess fluid around the gallbladder, together with ongoing gallbladder distension) (Figs. 2). We suggest that our patients should be classified as having a higher severity within TGI 3 grade II by considering the preoperative conditions which were previously mentioned.

Percutaneous cholecystostomy was performed in this patient group, considering that cholecystostomy might reduce both the inflammation and the risk of bile duct injury by postpon-

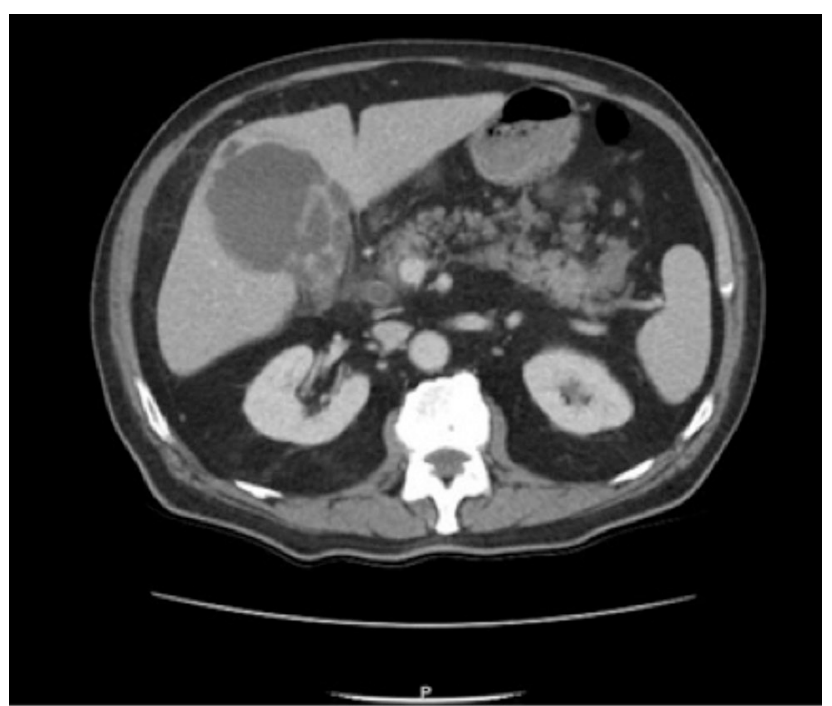

Figure 1. CT image of case with acute cholecystitis with perforation into the gallbladder bed. ing emergency surgery, enabling earlier discharge from the hospital (Fig. 3). PC is a well-defined, effective method for providing immediate decompression of the inflamed gallbladder in patients whose general condition is not suitable for emergency cholecystectomy. ${ }^{[10-14]}$ By this means, it helps early recovery by reversing the inflammatory process and shortens the duration of hospitalization. The response rate to percutaneous cholecystostomy varies between $56 \%$ and $100 \%$ in the literature. ${ }^{[12-17]}$ Boland et al. ${ }^{[12]}$ found that 17 (89\%) of 19 patients with a positive sonographic Murphy sign responded to PC, whereas only 29 (46\%) of 63 patients with a negative sonographic Murphy sign responded. The early complications of percutaneous cholecystostomy involve bleeding, vagal reactions, sepsis, biliary peritonitis, pneumothorax, intestinal perforation, secondary infection, and catheter dislodgement whereas its late complications are catheter dislodgement and recurrent cholecystitis. ${ }^{[18,19]}$ Major and minor complication rates vary between $3-8 \%$ and $4-13 \%$, respectively.

Although percutaneous cholecystostomy is a very effective method for resolving an acute clinical condition, it leads to

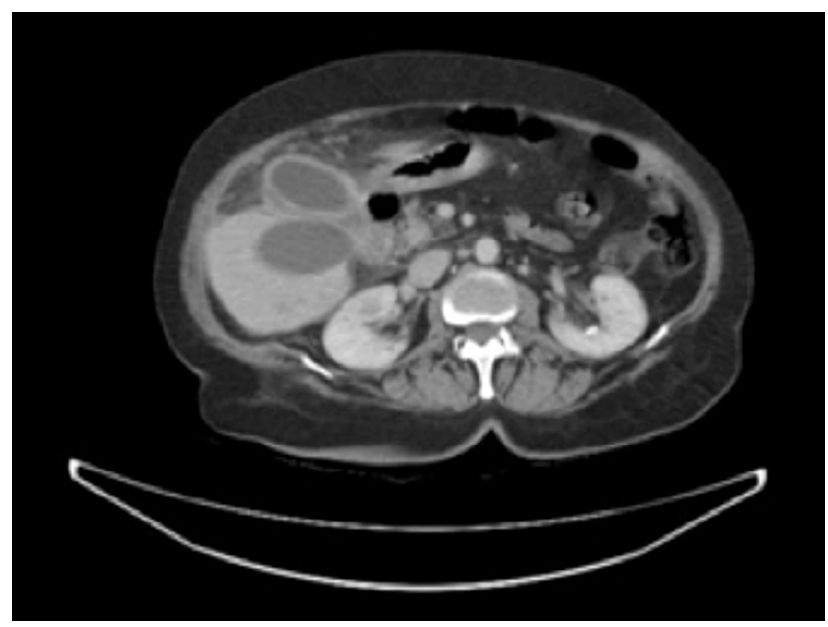

Figure 2. CT image of case with acute cholecystitis with perforation into the gallbladder bed but preserved gallbladder wall integrity.

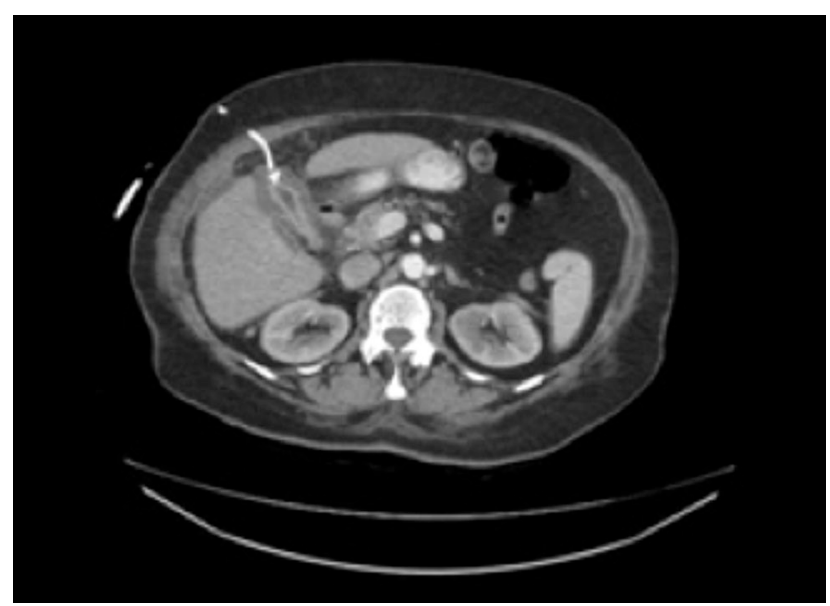

Figure 3. CT image of the same case after percutaneous cholecystostomy. 
the development of fibrosis between the corpus and the fundus of the gallbladder and the liver in most of the patients. ${ }^{[20]}$ Such development of fibrosis makes it more difficult to remove the gallbladder, and it was observed intraoperatively to develop in all patients (Fig. 4). Other studies have reported that cholecystectomy, when performed after cholecystostomy, is usually performed with laparoscopy. ${ }^{[6]}$ In a study, 245 patients had undergone cholecystostomy, and then, 7I of them underwent cholecystectomy. In 63 of them, the operation was started using a laparoscopic approach. In 13 of them, laparoscopic cholecystectomy was converted to open cholecystectomy, and in the remaining 50 patients, the operation was completed with laparoscopic cholecystectomy. [21] Based on this information, we started the operation with the laparoscopic approach in our first ten patients. However, the laparoscopic cholecystectomy was converted to open cholecystectomy in eight of them due to various difficulties encountered in the dissection of the Calot's triangle because of fibrosis. Based on our experience gained from the first ten patients, we performed open cholecystectomy in the following patients. We suggest that the reason for the higher conversion rate in our study compared to the rates of the studies mentioned above may be that our patients had additional findings, such as not responding to intravenous antibiotics or impaired gallbladder wall integrity, which increase the severity of cholecystitis even though they were classified as grade II according to the TGI 3 diagnostic criteria and severity grading of acute cholecystitis.

Although the Tokyo Guideline, which had been developed for classifying the severity of cholecystitis patients and was updated in 2013, is a guide for determining the treatment modality in patients with cholecystitis, grade II acute cholecystitis defined in the guideline has a broad spectrum. It can

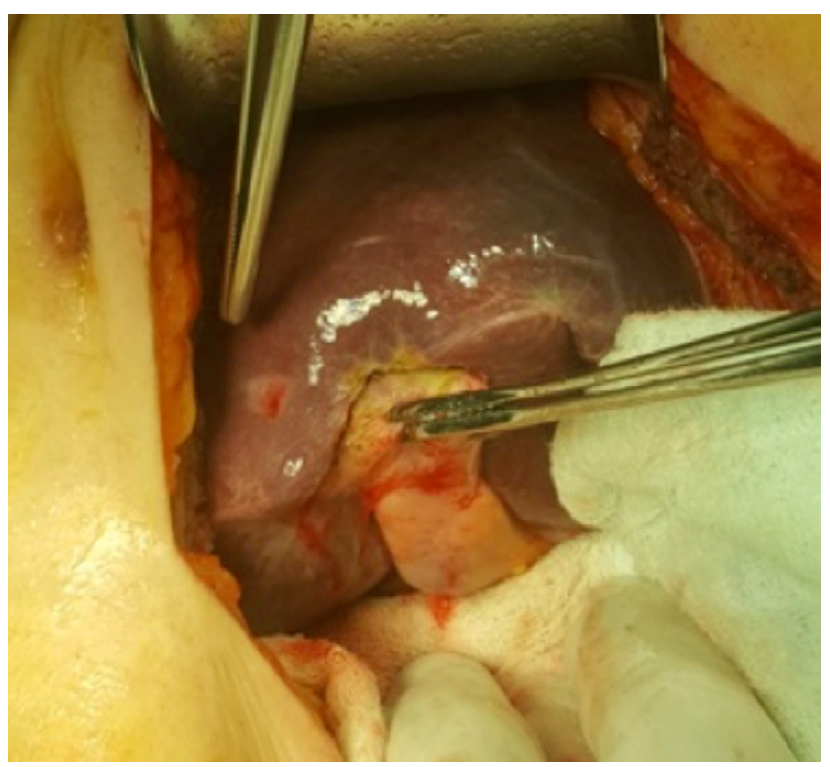

Figure 4. Perioperative image of a patient who underwent interval cholecystectomy showing the fibrosis around the gallbladder developed following percutaneous cholecystostomy. be suggested that grade II acute cholecystitis should be divided into subgroups to be more instructive regarding the modality of treatment. Even though cholecystostomy contributes to the improvement of the acute condition, we can also suggest that cholecystostomy should not be decided without thinking carefully especially in patients with grade I and II acute cholecystitis since it leads to fibrosis and that it should not be acted liberally in the preference of this type of intervention. Given that dense fibrosis develops during healing, especially in patients who do not respond well to intravenous antibiotics or have gallbladder perforation like our patients, we can say that percutaneous cholecystostomy will reduce the likelihood of performing laparoscopic cholecystectomy subsequently.

There is a need for a study involving a large number of patients with grade I and II acute cholecystitis for comparison of those necessitating long-term hospitalization and administration of intravenous antibiotics and hydration with the cholecystectomy patients necessitating short-term hospitalization only and having the early recovery advantage concerning interval cholecystectomy, assessing the conversion rate from laparoscopic to open cholecystectomy and the morbidity (bile duct injury). We have planned such a study in the Hepatobiliary and Organ Transplantation Unit, Department of General Surgery, Adnan Memderes University.

\section{Conclusion}

Although percutaneous cholecystostomy is a useful method for alleviation of the emergency clinical condition in acute cholecystitis, it makes the interval cholecystectomy more difficult to perform due to the dense fibrosis developing during the healing process. The previous study reports about the usual successful completion of a laparoscopic cholecystectomy following a cholecystostomy are in contradiction with our findings. The reason for this contradictory situation might be our patients having comorbidities, such as being unresponsive to intravenous antibiotics and gallbladder perforation, even though they were classified as grade II according to the TGI 3 diagnostic criteria and severity grading of acute cholecystitis. New studies are needed to explain whether cholecystostomy increases the rate of conversion from laparoscopic cholecystectomy to open cholecystectomy. Our results suggest that cholecystostomy may cause fibrosis during the healing process, eventually complicating laparoscopic cholecystectomy, and thus, there is a need for better evaluation during the identification of indications for cholecystostomy.

Ethics Committee Approval: Retrospective study.

Peer-review: Internally peer-reviewed.

Authorship Contributions: Concept: E.B.C.; Design: E.B.C.; Supervision: E.B.C.; Materials: E.B.C.; Data: E.B.C.; Analysis: E.B.C.; Literature search: E.B.C.; Writing: E.B.C.; Critical revision: K.K. 
Conflict of Interest: None declared.

Financial Disclosure: The autors declared that this study has received no financial support.

\section{REFERENCES}

1. Rassameehiran S, Tantrachoti P, Nugent K. Percutaneous gallbladder aspiration for acute cholecystitis. Proc (Bayl Univ Med Cent) 2016;29:3814. [CrossRef]

2. Ambe PC, Kaptanis S, Papadakis M, Weber SA, Zirngibl H. Cholecystectomy vs. percutaneous cholecystostomy for the management of critically ill patients with acute cholecystitis: a protocol for a systematic review. Syst Rev 2015;4:77. [CrossRef]

3. Takada T, Strasberg SM, Solomkin JS, Pitt HA, Gomi H, Yoshida M, et al; Tokyo Guidelines Revision Committee. TG13: Updated Tokyo Guidelines for the management of acute cholangitis and cholecystitis. J Hepatobiliary Pancreat Sci 2013;20:1-7.

4. Gomes CA, Junior CS, Di Saverio S, Sartelli M, Kelly MD, Gomes CC, et al. Acute calculous cholecystitis: Review of current best practices. World J Gastrointest Surg 2017;9:118-26. [CrossRef]

5. La Greca A, Di Grezia M, Magalini S, Di Giorgio A, Lodoli C, Di Flumeri G, et al. Comparison of cholecystectomy and percutaneous cholecystostomy in acute cholecystitis: results of a retrospective study. Eur Rev Med Pharmacol Sci 2017;21:4668-74.

6. Winbladh A, Gullstrand P, Svanvik J, Sandström P. Systematic review of cholecystostomy as a treatment option in acute cholecystitis. HPB (Oxford) 2009;11:183-93. [CrossRef]

7. Houghton PW, Jenkinson LR, Donaldson LA. Cholecystectomy in the elderly: a prospective study. Br J Surg 1985;72:220-2. [CrossRef]

8. Kirshtein B, Bayme M, Bolotin A, Mizrahi S, Lantsberg L. Laparoscopic cholecystectomy for acute cholecystitis in the elderly: is it safe?. Surg Laparosc Endosc Percutan Tech 2008;18:334-9. [CrossRef]

9. Morse BC, Smith JB, Lawdahl RB, Roettger RH. Management of acute cholecystitis in critically ill patients: contemporary role for cholecystostomy and subsequent cholecystectomy. Am Surg 2010;76:708-12.

10. Radder RW. Ultrasonically guided percutaneous catheter drainage for gallbladder empyema. Diagn Imaging 1980;49:330-3.

11. Akhan O, Akinci D, Ozmen MN. Percutaneous cholecystostomy. Eur J Radiol 2002;43:229-36. [CrossRef]

12. Boland GW, Lee MJ, Leung J, Mueller PR. Percutaneous cholecystostomy in critically ill patients: early response and final outcome in 82 patients. AJR Am J Roentgenol 1994;163:339-42. [CrossRef]

13. Vogelzang RL, Nemcek AA Jr. Percutaneous cholecystostomy: diagnostic and therapeutic efficacy. Radiology 1988;168:29-34. [CrossRef]

14. Chopra S, Dodd GD 3rd, Mumbower AL, Chintapalli KN, Schwesinger WH, Sirinek KR, et al. Treatment of acute cholecystitis in non-critically ill patients at high surgical risk: comparison of clinical outcomes after gallbladder aspiration and after percutaneous cholecystostomy. AJR Am J Roentgenol 2001;176:1025-31. [CrossRef]

15. Hatjidakis AA, Karampekios S, Prassopoulos P, Xynos E, Raissaki M, Vasilakis SI, et al. Maturation of the tract after percutaneous cholecystostomy with regard to the access route. Cardiovasc Intervent Radiol 1998;21:36-40. [CrossRef]

16. Browning PD, McGahan JP, Gerscovich EO. Percutaneous cholecystostomy for suspected acute cholecystitis in the hospitalized patient. J Vasc Interv Radiol 1993;4:531-8. [CrossRef]

17. Chang L, Moonka R, Stelzner M. Percutaneous cholecystostomy for acute cholecystitis in veteran patients. Am J Surg 2000;180:198-202.

18. vanSonnenberg E, D'Agostino HB, Goodacre BW, Sanchez RB, Casola G. Percutaneous gallbladder puncture and cholecystostomy: results, complications, and caveats for safety. Radiology 1992;183:167-70. [CrossRef]

19. van Overhagen H, Meyers H, Tilanus HW, Jeekel J, Laméris JS. Percutaneous cholecystectomy for patients with acute cholecystitis and an increased surgical risk. Cardiovasc Intervent Radiol 1996;19:72-6. [CrossRef]

20. Paran H, Zissin R, Rosenberg E, Griton I, Kots E, Gutman M. Prospective evaluation of patients with acute cholecystitis treated with percutaneous cholecystostomy and interval laparoscopic cholecystectomy. Int J Surg 2006;4:101-5. [CrossRef]

21. Khasawneh MA, Shamp A, Heller S, Zielinski MD, Jenkins DH, Osborn JB, et al. Successful laparoscopic cholecystectomy after percutaneous cholecystostomy tube placement. J Trauma Acute Care Surg 2015;78:100-4. [CrossRef]

\section{ORIJINAL ÇALIŞMA - ÖZET}

\section{Perkütan kolesistostomi yönetimi zor olan tüm olgularda yapılmalı mıdır? Dr. Erdem Barış Cartı, ${ }^{1}$ Dr. Koray Kutlutürk ${ }^{2}$}

${ }^{1}$ Adnan Menderes Üniversitesi Tıp Fakültesi, Genel Cerrahi Anabilim Dalı, Aydın

${ }^{2}$ Inönü Üniversitesi Tıp Fakültesi, Genel Cerrahi Anabilim Dalı, Malatya

AMAÇ: Kolesistektomi, cerrahiye uygun olan kolesistit hastalarında kabul görmüş bir tedavi yöntemidir. Perkütan kolesistostomi ise cerrahi açıdan yüksek riskli akut semptomlu kolesistit hastalarında geçici bir tedavi yöntemi olmakla beraber elektif kolesistektomi için hastaya zaman kazandırabilir. GEREÇ VE YÖNTEM: Bu çalışmada ultrason eşliğinde perkütan transhepatik kolesistostomi yapılmış ve dört-altı hafta sonra interval kolesistektomi uygulanmış olan 50 olgu sunuldu. Tüm hastalarda bilgisayarlı tomografide safra kesesi duvar bütünlüğünde bozulma veya Tokyo Guidelines I3 tanısal kriterlerine göre grade II akut kolesistit bulgusu saptanmış olup beş günlük tıbbi tedaviye yanıt alınamayan hastalara kolesistostomi işlemi yapılmasına karar verildi.

BULGULAR: Kolesistostomi her ne kadar akut kolesistit tablosunun yatışmasında etkili bir yöntem olsa da kolesistostomili olgularda dens fibrozis gelişimi nedeni ile yapılacak olan interval kolesistektominin daha komplike bir hal aldığı ve olgunun laparoskopik bitirilmesini zorlaştırdığı görülmüştür. TARTIŞMA: Kolesistostomi iyileşme süreci içerisinde dens fibrozis gelişimine neden olarak laparoskopik kolesistektomiyi daha komplike hale getirmektedir. Dolayısıyla kolesistostomi yapılacak olgular bu bilgi de göz önünde bulundurularak daha dikkatle seçilmelidir.

Anahtar sözcükler: Açık kolesistektomi; akut kolesisti; laparoskopik kolesistektomi; perkütan kolesistostomi.

Ulus Travma Acil Cerrahi Derg 2020;26(2):186-190 doi: 10.14744/tites.2020.73557 